(determines the value orientations of future specialists of the ORS of CD, possession of strategies for achieving the goals); strategic-informational (reflects the understanding of the essence of strategy as a system of effective regulatory actions that lead to the expected result; styles of collecting modern information on the basis of thinking operations - analysis, synthesis, abstraction, concretization, comparison, systematization, generalization); operational (involves the formation of different skills); reflexive-affective (the ability of the future specialist to self-analysis and adequate self-esteem, selfexpression of individuality). It is proved that the strategic competence of future specialists in higher education is an integrative unity of their personal and professionally significant qualities, which are acquired in the process of vocational training and consists of a system of values, motives, scientific and theoretical knowledge, practical skills, abilities, emotions, competences, emotions, adequate selection and implementation of effective strategies and tactics in different situations, ensuring successful selfrealization and self-improvement in the process of professional activity. The results of the study were realized using the diagnostic tools: "Employee Value Orientations" (M. Rokich), "Diagnosis of Goal Achievement Strategies", "Determination of Information Assimilation Style" (M. Fetiskin, V. Kozlov, G. Manuilov), "What is a Strategy teaching?" (author's methodology), "Assessment of communicative and organizational inclinations - COI" (V. Sinyavsky, B. Fedorishin), "Strategies of self-affirmation of personality" (E. Nikitin, N. Kharlamenkova). The results of the conducted pedagogical experiment showed the prevalence of productive (from $46.84 \%$ to $57.48 \%$ ) and reproductive (from $27.91 \%$ to $35.22 \%)$ levels of manifestation of the studied components of strategic competence of the respondents. It is proved that the empirical data obtained stimulate the development and implementation of a comprehensive development program for the formation of strategic competence of specialists of the operational and rescue service of civil defense in the practice of higher education institutions.

Keywords: strategic competence, operational and rescue service of civil protection, training, structure of strategic competence, diagnosis of strategic competence.

DOI: https://doi.org/10.31392/NZ-npu-145.2019.16

УДК 378.146

Полімук Г. В.

\title{
КОМПЛЕКСНА МЕТОДИКА ДІАГНОСТИКИ КОНФЛІКТОЛОГІЧНОЇ КОМПЕТЕНТНОСТІ МАЙБУТНІХ УЧИТЕЛІВ ІНОЗЕМНИХ МОВ
}

У статті розглянуто особливості педагогічної діагностики, ї̈ відмінність від психологічної діагностики, поради щодо підбору діагностичного інструментарію. Згідно визначеної структури конфліктологічної компетентності запропонована комплексна діагностика рівнів сформованості досліджуваного феномена: когнітивно-рефлексивний компонент - методика дослідження міжособистісного сприйняття у конфліктній ситуації (А. Тащевої у модифікаџії О. Місенко); самооцінка кругозору з конфліктології (С. Калаур); визначення рівнів сформованості педагогічної рефлексії (О. Калашнікової); мотивачійноціннісний компонент - діагностика мотиваційних орієнтацій у міжособистісних комунікаціях (І.Ладанова, В. Уразаєвої); тест “Наскільки Ви толерантні?” (О. Тупканової); “Експресдіагностика стійкості до конфліктів" (М. Фетіскіна, В. Козлова, Г. Мануйлова); операційнокорегувальний компонент - тест "Стиль поведінки в конфліктній ситуації" (К. Томаса); методика "Очінка рівня компетентності у виріменні конфліктів" (П. Хеппнер, І. Петерсен). 
Автором проведено експериментальне дослідження з використанням запропонованої комплексної діагностики, проаналізовано його результати.

Ключові слова: конфліктологічна компетентність, майбутні вчителі іноземних мов, діагностичні методики, комплексна методика діагностики.

Сьогодні на вчителя іноземної мови в сучасній українській школі покладається завдання навчання молоді різних мов, що забезпечує їм у майбутньому значні можливості для розширення ділових, професійних і культурних контактів, долучення до світової культури, підвищення рівня професійної та соціальної мобільності. Однак, зворотною стороною комунікації $€$ ризики виникнення непорозуміння між людьми, різних конфліктних ситуацій, які супроводжуються стресом і емоційним напруженням, що негативно впливає на стан здоров'я його учасників. Таким чином, для учителів і їх учнів важливим $€$ сфрормованість конфліктологічної компетентності. Особливої уваги для майбутніх учителів іноземних мов набуває визначення первинних, вихідних рівнів розвитку досліджуваного феномена, які визначаються за допомогою діагностичних методик і дають можливість отримувати кількісні і якісні характеристики цих об'єктів. Отже, у процесі проведення експериментального дослідження значна роль відводиться педагогічній діагностиці як засобу вимірювання індивідуально-психологічних якостей особистості або інших показників.

Різні аспекти проблеми педагогічної діагностики (сутність і завдання педагогічної діагностики, їі значення в освітньому процесі, роль у підвищенні якості освіти майбутніх фахівців, основні вимоги до педагогічної діагностики, використання різних форм і методів діагностики) розглядається в працях таких науковців як Б. Бітінас, Н. Бордовська, О. Войтовська, В. Галузяк, К. Інгенкамп, Н. Кузьміна, О. Реан, І. Холковська та ін. За допомогою діагностичних методик проводяться динамічні обстеження респондентів із фіксуванням результатів динаміки змін на різних етапах експериментальної роботи. Питання особливостей застосування педагогічної діагностики розглядаються у працях таких науковців як Т. Іщенко, О. Дука, Б. Кобзар, О. Матвєєва, Н. Менчинська, І. Підласий та ін.

Формулювання цілей статті - з'ясувати особливості застосування педагогічної діагностики у сучасних дослідженнях; розробити і апробувати комплексну методику діагностики конфліктологічної компетентності майбутніх учителів іноземних мов.

У психології і педагогіці, що активно використовують діагностичний інструментарій, $є$ певні відмінності у дослідженнях. Погоджуємося 3 О. Матвєєвою, яка зазначає, що психодіагностика більшою мірою прагне оцінити психіку людини, особистість, окремі психічні процеси, стани, властивості, соціально-психологічні явища, а педагогічна діагностика спрямована значною мірою на результати формування особистості - рівень профресійного й особистісного розвитку, підготовленості, вихованості, навченості й ін., на пошук причин цих результатів і характеристику цілісної педагогічної системи й цілісної особистості [5]. Отже, психодіагностика і педагогічна діагностика націлені на різні аспекти організації дослідження, 
враховують домінуючу спрямованість діагностики на вирішення психологічних або педагогічних завдань. Однак, одна та друга діагностики передбачають використання комплексу методик для з'ясування рівнів розвитку досліджуваних френоменів.

Т. Іщенко, О.Дука виділяють такі основні фрункції педагогічної діагностики: з'ясування стану об'єкта діагностики і встановлення відхилень від норм; інтегративна (об'єднання у цілісну картину розвитку об'єкта раніше відомих і отриманих діагностичних даних); прогностична (відпрацювання прогнозів вірогідних тенденцій розвитку об'єкта та відповідних корегувальних заходів) [2, с.69]. Отже, педагогічна діагностика проводиться із позицій предмета педагогіки як науки і ставить за мету створення педагогічного діагнозу на основі раніше відомих і нових діагностичних даних, а також проведення педагогічних корегувальних заходів. Таким чином, як зазначає І. Підласий, “діагностування перебуває у нерозривному зв'язку 3 прогнозуванням та проектуванням, які логічно завершують ланцюжок дослідницької процедури" [7, с. 10].

Преважна кількість діагностичних методик $€$ бланковими, де досліджуваним пропонуються серії запитань або тверджень, відповіді на яких дають змогу визначити рівні розвитку знань, умінь, навичок, якостей особистості та ін.

У процесі підбору діагностичного інструментарію для проведення експериментального дослідження враховувалися поради ряду науковців (В. Горленко, В. Острової, В. Панка, Н. Сосновенко, І. Ткачук):

- діагностичні методики мають бути перевіреними на практиці, бути валідними і мати відомості про експертизу, яку вони пройшли;

- перелік методик має складати деякий мінімум, який знадобиться у вирішенні типових і найбільш розповсюджених у практиці роботи проблем учасників освітнього процесу;

- діагностичний мінімум має бути структурований за основними цільовими аудиторіями і рівнями освіти;

- методики мають бути простими у практичному застосуванні, найбільш поширеними серед професійного співтовариства і не потребувати багато часу для їх вивчення [1, с. 5-6].

Особливого значення у проведенні нашого педагогічного дослідження відігравав підбір надійних і валідних діагностичних методик, що надавали можливість об'єктивно оцінити окремі прояви досліджуваного феномена. У дослідженні здійснювався якісний підбір методик педагогічної діагностики 3 урахуванням компонентного складу і показників конфліктологічної компетентності майбутніх учителів іноземних мов, а саме:

- когнітивно-рефлексивний компонент (наявність інтегрованих знань у галузі конфліктології; готовність до толерантного сприйняття соціальних і культурних відмінностей, шанобливого ставлення до історичної спадщини та культурних традицій людей різних національностей; рефлексія власної поведінки);

- мотиваційно-ціннісний компонент (спрямованість на конструктивне 
вирішення конфлікту; толерантність у ставленні до інших людей; емоційна стійкість в стресових ситуаціях; прагнення до співпраці та пошуку компромісних рішень);

- операційно-корегувальний (уміння проектувати власну взаємодію та розв'язувати конфлікти; вміння впливати на оцінки й судження опонентів; володіння технологіями і стратегіями вирішення конфрліктів; уміння організовувати роботу в постконфрліктній ситуації).

Отже, у процесі дослідження було використано наступні діагностичні методики:

- когнітивно-рефрлексивний компонент - методика дослідження міжособистісного сприйняття у конфлліктній ситуації (А. Тащевої у модифікації О. Місенко) [6, с. 23-27]; самооцінка кругозору з конфліктології (С. Калаур) [3, с.558-558]; визначення рівнів сформованості педагогічної рефлексії (О. Калашнікової) [4];

- мотиваційно-ціннісний компонент - діагностика мотиваційних орієнтацій у міжособистісних комунікаціях (І. Ладанова, В. Уразаєвої) [10, с. 6869]; тест "Наскільки Ви толерантні?" (О. Тушканової) [9, с. 357-359]; "Експресдіагностика стійкості до конфрліктів" (М. Фетіскіна, В. Козлова, Г. Мануйлова) $[10$, c. 149];

- операційно-корегувальний компонент - тест "Стиль поведінки в конфрліктній ситуації" (К. Томаса) [8, с. 29-34]; методика "Оцінка рівня компетентності у вирішенні конфліктів” (П. Хеппнер, І. Петерсен) [11, с. 66-75].

Коротко охарактеризуємо психолого-педагогічний інструментарій проведення дослідження.

Методика міжособистісного сприйняття у конфліктній ситуації (А. Тащевої у модифікації О. Місенко) [6, с. 23-27] має на меті дослідження особливостей сприйняття студентами поняття “конфлікт”, виявлення звичних для них способів розв'язання конфліктів, рівня конфліктності та згуртованості групи. Ця методика складається із двох завдань: перше - передбачає ступінь розуміння респондентами поняття "конфлікт" за допомогою їх оцінювання методом конвент-аналізу у відповідності до певної шкали; друге - спрямовано на визначення змістової близькості слова "конфлікт" 3 21-им спорідненим словом (незгода, бійка, сварка, суперечка, сутичка, скандал, битва, боротьба, лайка, розбрат, протиріччя, розлад, рукопашна, сперечання, бій, розбіжність, чвари, опір, наклеп, прочуханка, непорозуміння), які потрібно розподілити на відрізку прямої справа та зліва від терміну “конфрлікт". Слова, що розміщені на перших трьох поділках справа й зліва від букви К (“конфлікт”) становлять семантичне ядро цього терміну. За допомогою цієї методики отримується середня емоційна значущість (психологічна насиченість) даного слова в опитуваній групі.

Методика “Самооцінка кругозору з конфоліктології” (С. Калаур) [3, с.558558] спрямована на визначення рівнів розвитку знань; умінь; здатностей із педагогічної конфліктології, які можна оцінити на основі самооцінки власних дій у ситуаціях переговорів, веденні суперечок і дискусій, вирішенні конфліктів. Від студентів вимагається надати за 9-бальною шкалою оцінку того, що вони 
знають, вміють і на що вони здатні (за 7-ма аспектами). Респонденти також можуть прорахувати в балах, який вони мають рівень готовності до вирішення конфрліктів, а саме: рівень розвитку 7-25 - низький; 26-44 - середній; 45-63 високий.

Діагностична методика “Визначення рівнів сфрормованості педагогічної рефолексії" (за О. Калашніковою) [4] передбачає визначення рівнів розвитку пізнання самого себе. Діагностика має структуру особистісного опитувальника, що складається із 34 питань, на які потрібно дати відповідь “так" або “ні". Студентам пропонується відповісти на ряд запитань, позначивши свою згоду знаком “+”, а незгоду - знаком “-” з лівої сторони від номера питання. Для визначення рівня сформованості педагогічної рефлексії зіставляються результати, отримані в процесі проведення діагностики, з ключем для її обробки. За кожну правильну відповідь, що співпадає з ключем, респонденти отримують - 1 бал, в протилежному - 0 балів. Усі отримані бали підсумовуються й свідчать про рівні розвитку педагогічної рефлексів: від 0 до 11 балів - низький рівень, від 12 до 22 балів - середній рівень; від 23 до 34 балів - високий рівень рефлексії.

Діагностика мотиваційних орієнтації в міжособистісних комунікаціях (І. Ладанова, В.Уразаєвої) [10, с. 68-69] має на меті визначення основних комунікативних орієнтацій та їх гармонійності у процесі формального спілкування. Студентам пропонується вибрати один із варіантів відповідей (саме так; майже так; здається, так; може бути, так) на 20 запропонованих їм тверджень із опорою на власний досвід спілкування респондентів із партнерами. Потім за допомогою ключа визначаються комунікативні орієнтації, а саме: на прийняття партнера; на адекватність сприйняття і розуміння партнера; на досягнення компромісу. Діапазон кожної орієнтації - від 7 до 28 балів. Кількісна значимість відповідей (у балах) визначається наступним чином: саме так - 4 бали; майже так - 3 бали; здається, так - 2 бали; може бути, так - 1 бал. Загальний сумарний показник, що характеризує абсолютну гармонійність комунікативних орієнтацій, дорівнює 84 балам. Про ступінь виразності комунікативних орієнтацій, які проявляються у процесі спілкування і розв'язання конфліктів, можна судити на підставі наступних бальних проявів: 64 і більше - високий рівень; 30-63 - середній рівень; 29 і менше - низький рівень.

Тест “Наскільки Ви толерантні?” (О. Тушканової) [9, с. 357-359] надає можливість визначити рівень толерантності особистості. Респондентам пропонується дати правдиві відповіді на 9 запитань тесту типу “да" і "ні”. По 2 бали надається за відповіді: 1б, 2б, 3б, 46, 56, 6б, 7б, 8б, 9б. За інші варіанти відповідей бали не нараховуються. Загальна кількість отриманих балів свідчить про рівні розвитку толерантності досліджуваних: від 0 до 4 балів низький рівень, від 6 до 12 балів - середній рівень; від 14 до 18 балів - високий рівень.

Експрес-діагностика стійкості до конфрліктів (М. Фетіскіна, В. Козлова, Г. Мануйлова) [10, с.149] дозволяє визначити емоційну стійкість особистості у процесі розв'язання конфрліктів. Респондентам пропонується прочитати і 
оцінити за п'ятибальною шкалою кожне 3 десяти полярних суджень діагностичної методики, які найбільш властиві його поведінці. Проміжна графа 3 означає рівнозначну присутність обох якостей. Крайні значення бальної шкали (4-5 або 1-2) характеризують або ухиляння від спорів, або участь у розв'язанні конфліктних питань. Студенти оцінюють 3 лівої сторони запропонованої експрес-діагностики, наскільки у них проявляються наведені властивості. Підрахунок загальної кількості отриманих балів засвідчує рівні стійкості досліджуваних до конфліктів, а саме: 40-50 балів - високий рівень; 3039 балів - середній рівень; менше 29 балів - низький рівень конфоліктостійкості.

Методика "Стиль поведінки в конфоліктній ситуації” (К. Томаса) [8, с. 2934] показує типову реакцію особистості на конфлікт, дає інформацію про інші способи вирішення конфліктної ситуації. Для опису типів поведінки людей у конфліктних ситуаціях К. Томас використовує двовимірну модель регулювання конфліктів, яка проявляється у кооперації й пов'язана з увагою людини до інтересів інших людей у конфлікті, та невідступності, для якої $є$ характерним акцент на захист власних інтересів, упертість, натиск. Відповідно до цих двох вимірів виділяються п'ять основних способів урегулювання конфліктів:

1) змагання (конкуренція) як прагнення досягти своїх інтересів на шкоду іншому;

2) пристосування як принесення у жертву власних інтересів заради іншого;

3) компроміс як бажання завершити конфлікт частковими поступками, готовність визнати претензії іншої сторони частково обґрунтованими;

4) уникнення як прагнення до кооперації й досягнення власних цілей;

5) співпраця як прагнення до конструктивного обговорення проблеми, розгляд іншої сторони не як противника, а як союзника в пошуку рішення.

Ці стратегії поведінки визначаються у методиці за допомогою ключа опитувальника при виборі респондентами варіантів поведінки (“а” або “б”) у 30 ситуаціях.

Методика “Оцінка рівня компетентності у вирішенні конфрліктів" (П. Хеппнер, І.Петерсен) [11, с. 66-75] спрямована на виявлення конфліктологічної компетентності особистості на основі її самооцінки. Досліджувані оцінюють 18 наведених тверджень відповідно до запропонованої шкали оцінювання: 4 бали - "цілком вірно”, 3 бали - “швидше вірно”; 2 бали "швидше невірно"; 1 бал - “невірно”. Підрахунок загальної кількості набраних респондентами балів дає можливість визначити рівні компетентності у вирішенні конфліктів: від 18 до 48 балів - низький; від 49 до 60 балів середній; від 61 до 72 балів - високий рівні.

Висновки. Обраний психодіагностичний інструментарій використовувався у процесі дослідження рівнів сформованості конфліктологічної компетентності майбутніх учителів іноземних мов, який відбувався на стандартизованій вибірці - 315 досліджуваних.

На основі емпіричних даних, отриманих у констатувальному експерименті, визначено загальний рівень сформованості конфліктологічної компетентності в 
майбутніх учителів іноземних мов. На вхідному етапі експериментальної роботи в майбутніх учителів іноземних мов найбільший відсоток осіб за високим рівнем виявлено в прояві мотиваційно-ціннісного компонента $(23,81 \%)$. Відсоток досліджуваних за вказаним компонентом (у порівнянні 3 іншими) із його низьким рівнем теж зафріксовано на найнижчому рівні (18,73\%).

Когнітивно-рефлексивний й операційно-коригувальний компоненти за рівнями відрізнялися між собою у незначних відсотках, а саме: 17,14\% і 16,83\% (високий); 47,62\% і 46,35\% (середній); 35,24\% і 36,82\% (низький).

Загальний рівень сфрормованості конфлліктологічної компетентності майбутніх учителів іноземних мов за результатами констатувального експерименту $\epsilon$ невисоким і потребує його підвищення: високий рівень виявлено в 19,36\% респондентів, середній - у 50,48\%, а низький - у 30,16\%.

Отже, за результатами аналізу отриманих даних експерименту можна стверджувати, що респонденти продемонстрували деяку адекватність сприйняття конфліктної ситуації, виявляли певну самостійність при виборі способів взаємодій у конфліктних ситуаціях, інколи проявляли толерантність до думок опонентів тощо. У той же час респонденти в переважній більшості були не спроможні до видобування планів і стратегій розв'язання конфрліктів, їх дії у конфліктних ситуаціях виявляли ознаки непередбачуваності й надмірної емоційності, що засвідчувало недостатній розвиток у них конфліктологічної компетентності.

Результати подальших розвідок вбачаємо у розробці та апробації на практиці розвивальної програми формування конфліктологічної компетентності майбутніх учителів іноземних мов і виявлення рівнів сорормованості досліджуваного феномена після проведення експериментальної роботи.

\section{Використана література:}

1. Застосування діагностичних мінімумів в діяльності працівників психологічної служби : [метод. рек.] / авт.-упор.: В. М. Горленко, В. Д. Острова, Н. В. Сосновенко, І. І. Ткачук ; за заг. ред. В. Г. Панка. Київ : УНМЦ практичної психології і соціальної роботи, 2018. 106 с.

2. Іщенко Т. В., Дука О. А. Теоретичні основи педагогічної діагностики у вищій військової школі. Вісник Національного університету оборони Украӥни. 2013. № 1 (32). С. 66-71.

3. Калаур С. М. Система професійної підготовки майбутніх фахівців соціальної сфери до розв'язання конфліктів у професійній діяльності : дис. ... доктора пед. наук: 13.00.04 / Тернопільський нац.. пед. ун-т ім. Володимира Гнатюка. Тернопіль, 2018. 676 с.

4. Калашникова О. В. Психологические особенности развития педагогической рефлексии: дис. ... канд. психол. наук: 19.00.07. СанктПетербург, 1999. 205 с.

5. Матвєєва О. О. Особливості педагогічної діагностики. Педагогіка та психологія. 2012. Вип. 41. C. 5-16. URL: http://nbuv.gov.ua/UJRN/znpkhnpu_ped_2012_41_3.

6. Мисенко О. В. Модификация методики исследования особенностей межличностного восприятия в конфликтной ситуации. Практична психологія та соиіальна робота. 2005. № 5. С. 23-27.

7. Підласий І. П. Діагностика та експертиза педагогічних проектів : навч. посіб. Київ : Україна, 1998. 343 с.

8. Сотська Г., Тітаренко I. Посібник-практикум з формування конфліктологічної компетентності майбутніх фахівців з реклами і зв’язків з громадськістю. Київ : ТОВ “ДКС Центр”, 2018. 48 с.

9. Тушканова О. И. Насколько Ви терпимы? Толерантное сознание и формирование толерантных отношений (теория и практика) : сб. науч.-метод. ст. Москва: [б. и.], 2002. С. 357-359.

10. Фетискин Н. П., Козлов В. В., Мануйлов Г. М. Социально-психологическая диагностика развития личности и малых групп. Москва : Из-во Институту Психотерапии, 2002. 490 с. 
11. Heppner P. P., Petersen Ch. H. Development and Implication of a Personal Problem Solving Inventory. Journal of Counseling Psychology. 1982. № 29. P. 66-75.

\section{References:}

[1] Zastosuvannia diahnostychnykh minimumiv $\mathrm{v}$ diialnosti pratsivnykiv psykholohichnoi sluzhby [Application of diagnostic minimums of employees of the psychological service]: [metod. rek.] / avt.upor.: V. M. Horlenko, V. D. Ostrova, N. V. Sosnovenko, I. I. Tkachuk; za zah. red. V. H. Panka. (2018). Kyiv: UNMTs praktychnoi psykholohii i sotsialnoi roboty. $106 \mathrm{c}$.

[2] Ishchenko, T. V., Duka, O. A. (2013). Teoretychni osnovy pedahohichnoi diahnostyky u vyshchii viiskovoi shkoli [Theoretical bases of pedagogical diagnostics in higher military school]. Visnyk Natsionalnoho universytetu oborony Ukrainy. №1 (32). S. 66-71.

[3] Kalaur, S. M. (2018). Systema profesiinoi pidhotovky maibutnikh fakhivtsiv sotsialnoi sfery do rozviazannia konfliktiv u profesiinii diialnosti [The system of professional training of future social professionals to resolve conflicts in professional activities]: dys. ... doktora ped. nauk: 13.00.04 / Ternopilskyi nats.. ped. un-t im. Volodymyra Hnatiuka. Ternopil, 676 s.

[4] Kalashnikova, O. V. (1999). Psihologicheskie osobennosti razvitiya pedagogicheskoy refleksii [Psychological features of the development of pedagogical reflection] : dis. ... kand. psihol. nauk: 19.00.07. SanktPeterburg, $205 \mathrm{~s}$.

[5] Matvieieva, O. O. (2012). Osoblyvosti pedahohichnoi diahnostyky [Features of pedagogical diagnostics]. Pedahohika ta psykholohiia. Vyp.41. S. 5-16. URL: http://nbuv.gov.ua/UJRN/znpkhnpu_ped_2012_41_3.

[6] Misenko, O. V. (2005). Modifikatsiya metodiki issledovaniya osobennostey mezhlichnostnogo vospriyatiya $\mathrm{v}$ konfliktnoy situatsii [Modification of the methodology for studying the characteristics of interpersonal perception in a conflict situations]. Praktychna psykholohiia ta sotsialna robota. № 5. S. 23-27.

[7] Pidlasyi, I. P. (1998). Diahnostyka ta ekspertyza pedahohichnykh proektiv [Diagnosis and examination of pedagogical projects]: navch. posib. Kyiv: Ukraina, $343 \mathrm{~s}$.

[8] Sotska, H., Titarenko, I. (2018). Posibnyk-praktykum z formuvannia konfliktolohichnoi kompetentnosti maibutnikh fakhivtsiv z reklamy i zviazkiv z hromadskistiu [Workshop on the formation of conflict competence of future professionals in advertising and public relations]. Kyiv: TOV "DKS Tsentr", $48 \mathrm{~s}$.

[9] Tushkanova, O. I. (2002). Naskolko Vi terpimyi? [How tolerant are you?]. Tolerantnoe soznanie i formirovanie tolerantnyih otnosheniy (teoriya i praktika): sb. nauch.-metod. st. Moskva: [b. i.], S. 357359.

[10] Fetiskin, N. P., Kozlov, V. V., Manuylov G. M. (2002). Sotsialno-psihologicheskaya diagnostika razvitiya lichnosti i malyih grupp [Socio-psychological diagnosis of the development of personality and small groups]. Moskva: Iz-vo Institutu Psihoterapii, $490 \mathrm{~s}$.

[11] Heppner, P. P., Petersen, Ch. H. (1982). Development and Implication of a Personal Problem Solving Inventory. Journal of Counseling Psychology. № 29. P. 66-75.

\section{ПолищукА. В. Комплексная методика диагностики конфликтологической компетентности будущих учителей иностранных языков. \\ В статье рассмотрены особенности педагогической диагностики, ее отличие от} психологической диагностики, советы по подбору диагностического инструментария. Согласно определенной структуры конфликтологической компетентности предложена комплексная диагностика уровней сформированности исследуемого феномена: когнитивнорефлексивный компонент - методика исследования межличностного восприятия в конфликтной ситуачии (А. Тащевой в модификаџии А. Мисенко) самооценка кругозора по конфликтологии (С. Калаур) определение уровней сформированности педагогической рефлексии (А. Калашниковой) мотивачионно-иенностный компонент - диагностика мотивационных ориентаџий в межличностных коммуникащиях (И. Ладанова, В. Уразаевой) тест "Насколько Bbl толерантны?" (А. Тушканова) “Экспресс-диагностика устойчивости к конфликтам” (М. Фетискина, В. Козлова, Г. Мануйлова) операчионно-корректирующий компонент - тест “Стиль поведения в конфликтной ситуащии” (К. Томаса), методика “Оџенка уровня компетентности в решении конфликтов” (П.Хеппнер, И. Петерсен). Автором проведено экспериментальное исследование с использованием предложенной комплексной диагностики, проанализированы его результаты. 
Ключевые слова: конфликтологическая компетентность, будущие учителя иностранных языков, диагностические методики, комплексная методика диагностики.

POLISCHCHUK A. V. Complex methodology of diagnosis of conflictological competence of future teachers of foreign languages.

The article examines the features of pedagogical diagnostics, its difference from psychological diagnostics, and tips on the selection of diagnostic tools. According to a certain structure of conflictological competence, the next comprehensive diagnosis of the levels of formation of the phenomenon under study is proposed: a cognitive-reflective component - a methodology for studying interpersonal perception in a conflict situation (A. Tashchev as modified by A. Misenko) self-assessment of horizons by conflictology ( $S$. Kalaur) determination of the levels of formation of pedagogical reflection (A. Kalashnikova) value-motivational component - diagnosis of motivational orientations in interpersonal communications (I. Ladanov, V. Urazaeva) test "How tolerant are you?" (A. Tushkanov) "Expressdiagnostics of resistance to conflicts" (M. Fetiskin, V. Kozlov, G. Manuylov) corrective-operational component - test "Behavior style in a conflict situation" ( $K$. Thomas), methodology "Assessment of the level of competence in conflicts resolving” (P. Heppner, I. Petersen). An experimental study was conducted using the proposed integrated diagnosis, and its results has been analyzed by the author.

Keywords: conflictological competence, future teachers of foreign languages, diagnostic techniques, comprehensive diagnostic technique.

DOI: https://doi.org/10.31392/NZ-npu-145.2019.17

УДК [378.018.8:373.5011.3-051:62]:331.5

Потапкін В.

\section{СПЕЦИФІКА РЕАЛІЗАЦІЇ МІЖПРЕДМЕТНИХ ЗВ'ЯЗКІВ У ПРОЦЕСІ ПРОФЕСІЙНОЇ ПІДГОТОВКИ МАЙБУТНІХ УЧИТЕЛІВ ТРУДОВОГО НАВЧАННЯ}

У статті розглянуті питання оптимізації процесу професійної підготовки майбутніх учителів трудового навчання, які повинні оволодіти високим рівнем технічних, технологічних здібностей, інноваційного творчого мислення, оперування великими обсягами інформації, володіння методологією конструкторської діяльності. Одним із шляхів вирімення даного завдання є обтрунтування процесу реалізащії міжпредметних зв'язків під час вивчення дисииплін блоку професійної підготовки. Модель сучасного освітнього процесу підготовки майбутніх учителів трудового навчання може бути представлена як ієрархічна структура, елементами якої є одиниці навчального плану - дисципліни, щзо вивчаються.

Ключові слова: професійна підготовка, міжпредметні зв'язки, диференціація, інтеграція, дидактичні функиї міжпредметних зв 'язків, зв 'язок теорії і практики.

Зростаючі темпи модернізації виробництва, зміна змісту праці, потреби мобільного переходу від однієї професії до іншої в умовах сучасного динамічного розвитку виробництва, виникнення нових професій значно підвищили вимоги до рівня підготовки майбутніх учителів трудового навчання. А це, в свою чергу, актуалізувало потребу взаємоузгодженого вивчення 